\title{
Interactive comment on
}

\section{"Temperature-dependence of aerosol optical depth over the southeastern US" by Tero Mielonen et al.}

\section{Anonymous Referee \#2}

Received and published: 19 August 2016

In this paper, the authors examine a temperature dependence of AOD in the southeastern US using satellite observations and model output. They determine a linear fit between AOD anomalies and land surface temperature anomalies and suggest this positive trend is mainly due to non-anthropogenic emissions, specifically biogenic VOC emissions.

My overall impression is that the authors do not present any new scientific insight. They discuss the Goldstein et al., 2009 paper but not many of the more recent papers (only Attwood et al., 2014; Ford and Heald, 2013; Hidy et al., 2014) that have looked at this region in detail or that present findings from the SAS/SOAS/SENEX/SEAC4RS campaigns in 2013 (yes, I know this satellite product is only to 2012 but the findings

Printer-friendly version

Discussion paper 
are relevant to the region, see Hidy et al. (2014) for comparison of 2013 to previous decade of observations). While they do use a new AOD product, it is not compared to other AOD datasets used in previous studies of the region, and the authors rely on correlations of anomalies without a thorough description of processes that I think are better discussed in other papers. My recommendation is therefore to reject.

I have several more specific points that I think should have been addressed and some statements that I found confusing.

In particular, this specific AOD product from AATSR is relatively new (the Kolmonen et al., 2016 paper was published earlier this year). Therefore, I would have appreciated a greater description and validation of the product over this particular region. The Kolmonen et al. (2016) paper gives global validation statistics for the full time period (using binned AOD), so I'm unsure if there are any regional differences. The authors present anomalies of regional, summertime average AOD, which makes it hard to get a feel for the data. The authors should have shown some comparison with AERONET measurements and MODIS or MISR, specifically over the southeastern US. Additionally, I would like to have known: (1) How many observations went into each summer AOD calculation and what is the spatial distribution of these observations (the Kolmonen paper says observations are scarce, maybe available every 3-4 days at midlatitudes)? (2) Is there interannual variability in the number or spatial distribution of observations? (3) How much spatial variability is there in the AOD anomalies and trend in anomalies?

(4) Did the cloud filtering impact your results? Finally, I would like to have seen some discussion of the regional AOD (not just anomalies) and its trends compared to the AOD trends shown in other studies, such as Alston et al. (2012) and Attwood et al. (2014).

These concerns with the satellite product and calculation of the anomalies all make me question the radiative effects calculations, which already have really large uncertainties.

Printer-friendly version

Discussion paper
Interactive

comment 
There was no discussion of aerosol water and how that might impact AOD. Nguyen et al. (2015) showed that there was a significant decrease in aerosol water mass concentrations from 2001-2012 in the southeastern US and Attwood et al. (2014) showed that the decrease in AOD over the southeastern US was due to both reduced mass loading and reduced aerosol hygroscopicity.

Interactive

The authors state that anthropogenic emissions are the main driver of AOD levels in the region because they use NO2 columns as a proxy for anthropogenic pollution and NO2 columns are correlated with AOD (for the modeling, they use SO4 mass as a proxy for anthropogenic pollution). Studies have found that a large portion of the aerosol mass is organics (e.g., Attwood et al., 2014; Edgerton et al., 2006; Ford and Heald, 2013; Kim et al., 2015; Xu et al., 2015) with SOA predicted to be $40-90 \%$ of the organic mass (e.g., Ahmadov et al., 2012; Budisulistiorini et al., 2015; Lim and Turpin, 2002). The literature does strongly suggest that anthropogenic pollutants influence SOA formation (e.g., Budisulistiorini et al., 2015; Hoyle et al., 2011; Rattanavaraha et al., 2016; Volkamer et al., 2006; Xu et al., 2015), but I'm not sure this is what the authors are referring to when they are separating out the non-anthropogenic from anthropogenic contribution in the anomaly trends. It could be that decreasing anthropogenic emissions are leading to a decrease in SOA formation along with a decrease in inorganic aerosol mass. This kind of discussion is lacking in the paper. Separating into "anthropogenic" and "non-anthropogenic" may be too much of a simplification for the chemistry in this region.

Page 3, line 16-18: Just over land or the whole region?

Page 3, line 21-27: Authors should state the overpass time.

Page 4, line 5-10: Authors should state version of product. Also, how are clouds handled and AOD aggregated with regards to Level 3 ? It is not clear in the Kolmonen et al (2016) paper as the supplementary section describes clearing pixels and the main text discusses buddy checking in the final product, but l'm unsure of the impact on the

Printer-friendly version

Discussion paper 
Page 5, line 25: How does a reader see details of schemes in a paper that is in preparation?

Page 9, line 27-28: Unless the authors show that using daily vs. using the satellite overpass time does not have an impact, then it is not the right comparison. There should be diurnal variability in the aerosol mass loading (transportation has diurnal variability, photochemistry during the day, the southeastern US has interesting nighttime chemistry, eg. Xu et al., 2015; Ayres et al., 2015; water uptake is greater at night, e.g. Hidy et al., 2014, boundary layer impacts, e.g. Kim et al., 2015) and the trends may be different in daily vs. hourly, especially if there have been changes in the aerosol formation processes. Also, l'm confused by this comment that they only have daily because later (page 10, line 30), they discuss hourly results for their sensitivity simulations. The authors could at least look at one year and see how much difference it makes. Finally, did the authors also sample the model to the grid and days when the satellite had valid observations? Did this change their results at all?

Page 10, line 6: What do the authors mean that NO2 is not included in the model? Do they mean not included in the output? If so, why?

Page 10, Line 14-15: This is a bit concerning. Are there no emission factors to account for weekly or diurnal cycles? The authors should at least discuss in better detail what impact this might have on their results. If there is no diurnal variability in anthropogenic emissions, then Figure 6 is misleading. Additionally, did the authors do a sensitivity test where they turned off anthropogenic emissions?

Page 10, line 7-12: This is confusing, can the authors just give the percent (normalized mean bias? Or such) rather than "half" or "one third"?

Page 9, line 2-6: Most of the fires in the southeastern US are agricultural fires that do not produce much smoke, but the southeastern US also gets impacted by smoke from 
wildfires in the western US (as shown in Kim et al., 2015; Washenfelder et al., 2015).

Page 11, line 1, 9-11: Aren't biogenic emissions in the model a function of temperaACPD ture?

\section{References:}

Ahmadov, R., McKeen, S. A., Robinson, A. L., Bahreini, R., Middlebrook, A. M., de Gouw, J. A., Meagher, J., Hsie, E. Y., Edgerton, E., Shaw, S. and Trainer, M.: A volatility basis set model for summertime secondary organic aerosols over the eastern United States in 2006, J. Geophys. Res.-Atmospheres, 117, D06301, doi:10.1029/2011jd016831, 2012.

Alston, E. J., Sokolik, I. N. and Kalashnikova, O. V.: Characterization of atmospheric aerosol in the US Southeast from ground- and space-based measurements over the past decade, Atmospheric Meas. Tech., 5(7), 1667-1682, doi:10.5194/amt-5-16672012, 2012.

Attwood, A. R., Washenfelder, R. A., Brock, C. A., Hu, W., Baumann, K., CampuzanoJost, P., Day, D. A., Edgerton, E. S., Murphy, D. M., Palm, B. B., McComiskey, A., Wagner, N. L., de Sá, S. S., Ortega, A., Martin, S. T., Jimenez, J. L. and Brown, S. S.: Trends in sulfate and organic aerosol mass in the Southeast U.S.: Impact on aerosol optical depth and radiative forcing, Geophys. Res. Lett., 41(21), 2014GL061669, doi:10.1002/2014GL061669, 2014.

Ayres, B. R., Allen, H. M., Draper, D. C., Brown, S. S., Wild, R. J., Jimenez, J. L., Day, D. A., Campuzano-Jost, P., Hu, W., de Gouw, J., Koss, A., Cohen, R. C., Duffey, K. C., Romer, P., Baumann, K., Edgerton, E., Takahama, S., Thornton, J. A., Lee, B. H., Lopez-Hilfiker, F. D., Mohr, C., Wennberg, P. O., Nguyen, T. B., Teng, A., Goldstein, A. $\mathrm{H}$., Olson, K. and Fry, J. L.: Organic nitrate aerosol formation via $\mathrm{NO} 3$ + biogenic volatile organic compounds in the southeastern United States, Atmos Chem Phys, 15(23), 13377-13392, doi:10.5194/acp-15-13377-2015, 2015. 
Budisulistiorini, S. H., Li, X., Bairai, S. T., Renfro, J., Liu, Y., Liu, Y. J., McKinney, K. A., Martin, S. T., McNeill, V. F., Pye, H. O. T., Nenes, A., Neff, M. E., Stone, E. A., Mueller, ACPD S., Knote, C., Shaw, S. L., Zhang, Z., Gold, A. and Surratt, J. D.: Examining the effects of anthropogenic emissions on isoprene-derived secondary organic aerosol formation during the 2013 Southern Oxidant and Aerosol Study (SOAS) at the Look Rock, Tennessee ground site, Atmos Chem Phys, 15(15), 8871-8888, doi:10.5194/acp-15-88712015, 2015.

Edgerton, E. S., Hartsell, B. E., Saylor, R. D., Jansen, J. J., Hansen, D. A. and Hidy, G. M.: The Southeastern Aerosol Research and Characterization Study, part 3: continuous measurements of fine particulate matter mass and composition, J. Air Waste Manag. Assoc. 1995, 56(9), 1325-1341, 2006.

Ford, B. and Heald, C. L.: Aerosol loading in the Southeastern United States: reconciling surface and satellite observations, Atmos Chem Phys, 13(18), 9269-9283, doi:10.5194/acp-13-9269-2013, 2013. Hidy, G. M., Blanchard, C. L., Baumann, K., Edgerton, E., Tanenbaum, S., Shaw, S., Knipping, E., Tombach, I., Jansen, J. and Walters, J.: Chemical climatology of the southeastern United States, 1999-2013, Atmos Chem Phys, 14(21), 11893-11914, doi:10.5194/acp-14-11893-2014, 2014.

Hoyle, C. R., Boy, M., Donahue, N. M., Fry, J. L., Glasius, M., Guenther, A., Hallar, A. G., Huff Hartz, K., Petters, M. D., Petäjä, T., Rosenoern, T. and Sullivan, A. P.: A review of the anthropogenic influence on biogenic secondary organic aerosol, Atmos Chem Phys, 11(1), 321-343, doi:10.5194/acp-11-321-2011, 2011.

Kim, P. S., Jacob, D. J., Fisher, J. A., Travis, K., Yu, K., Zhu, L., Yantosca, R. M., Sulprizio, M. P., Jimenez, J. L., Campuzano-Jost, P., Froyd, K. D., Liao, J., Hair, J. W., Fenn, M. A., Butler, C. F., Wagner, N. L., Gordon, T. D., Welti, A., Wennberg, P. O., Crounse, J. D., St. Clair, J. M., Teng, A. P., Millet, D. B., Schwarz, J. P., Markovic, M. Z. and Perring, A. E.: Sources, seasonality, and trends of southeast US aerosol: an integrated analysis of surface, aircraft, and satellite observations with the GEOS-Chem 
chemical transport model, Atmos Chem Phys, 15(18), 10411-10433, doi:10.5194/acp15-10411-2015, 2015.

Kolmonen, P., Sogacheva, L., Virtanen, T. H., Leeuw, G. de and Kulmala, M.: The ADV/ASV AATSR aerosol retrieval algorithm: current status and presentation of a full-mission AOD dataset, Int. J. Digit. Earth, 9(6), 545-561, doi:10.1080/17538947.2015.1111450, 2016.

Lim, H.-J. and Turpin, B. J.: Origins of Primary and Secondary Organic Aerosol in Atlanta:âĂL' Results of Time-Resolved Measurements during the Atlanta Supersite Experiment, Environ. Sci. Technol., 36(21), 4489-4496, doi:10.1021/es0206487, 2002.

Nguyen, T. K. V., Capps, S. L. and Carlton, A. G.: Decreasing Aerosol Water Is Consistent with OC Trends in the Southeast U.S., Environ. Sci. Technol., 49(13), 7843-7850, doi:10.1021/acs.est.5b00828, 2015.

Rattanavaraha, W., Chu, K., Budisulistiorini, S. H., Riva, M., Lin, Y.-H., Edgerton, E. S., Baumann, K., Shaw, S. L., Guo, H., King, L., Weber, R. J., Neff, M. E., Stone, E. A., Offenberg, J. H., Zhang, Z., Gold, A. and Surratt, J. D.: Assessing the impact of anthropogenic pollution on isoprene-derived secondary organic aerosol formation in PM2.5 collected from the Birmingham, Alabama, ground site during the 2013 Southern Oxidant and Aerosol Study, Atmos Chem Phys, 16(8), 4897-4914, doi:10.5194/acp16-4897-2016, 2016.

Volkamer, R., Jimenez, J. L., San Martini, F., Dzepina, K., Zhang, Q., Salcedo, D., Molina, L. T., Worsnop, D. R. and Molina, M. J.: Secondary organic aerosol formation from anthropogenic air pollution: Rapid and higher than expected, Geophys. Res. Lett., 33(17), 2006.

Washenfelder, R. A., Attwood, A. R., Brock, C. A., Guo, H., Xu, L., Weber, R. J., Ng, N. L., Allen, H. M., Ayres, B. R., Baumann, K., Cohen, R. C., Draper, D. C., Duffey, K. C., Edgerton, E., Fry, J. L., Hu, W. W., Jimenez, J. L., Palm, B. B., Romer, P., 
Stone, E. A., Wooldridge, P. J. and Brown, S. S.: Biomass burning dominates brown carbon absorption in the rural southeastern United States, Geophys. Res. Lett., 42(2), 2014GL062444, doi:10.1002/2014GL062444, 2015.

Xu, L., Guo, H., Boyd, C. M., Klein, M., Bougiatioti, A., Cerully, K. M., Hite, J. R., Isaacman-VanWertz, G., Kreisberg, N. M., Knote, C., Olson, K., Koss, A., Goldstein, A. H., Hering, S. V., Gouw, J. de, Baumann, K., Lee, S.-H., Nenes, A., Weber, R. J. and $\mathrm{Ng}, \mathrm{N}$. L.: Effects of anthropogenic emissions on aerosol formation from isoprene and monoterpenes in the southeastern United States, Proc. Natl. Acad. Sci., 112(1), 37-42, doi:10.1073/pnas.1417609112, 2015.

Interactive comment on Atmos. Chem. Phys. Discuss., doi:10.5194/acp-2016-625, 2016. 